\title{
SUNGAI BARITO DALAM PERSEBARAN SUKU DAYAK DI KALIMANTAN BAGIAN TENGGARA
}

\section{BARTORMER ONDAYAKDISPERSAL INTHE SOUTHEASTERNPART OF KALMANIAN}

\author{
Hartatik \\ Balai Arkeologi Kalimantan Selatan, J alan Gotong Royong II, RT 03/06 Banjarbaru 70711 Kalimantan Selatan; \\ email: hartatik@ kemdikbud.go.id; tatitatibalar@ gmail.com
}

\begin{abstract}
Abstrak. Sungai Barito merupakan sungai besar yang berhulu di Pegunungan Schwaner Muller di bagian utara Kalimantan Tengah dan bermuara di Banjarmasin menuju Laut Jawa. Sebagai sungai terlebar di Indonesia, Barito terkenal sejak ratusan tahun silam hingga kini. Berbagai mitos dan legenda tercipta di sekitar aliran sungai ini. Situs-situs kuno tersebar dari hilir hingga hulu sungai, seperti situs Kerajaan Banjar di Banjarmasin, situs Patih Muhur di Batola, dan permukiman suku Dayak di bagian tengah hingga hulu Sungai Barito. Artikel ini akan membahas tentang keberadaan Sungai Barito (dan anak sungainya) kaitannya dengan persebaran suku Dayak di Kalimantan bagian tenggara. Tujuan dari tulisan ini adalah mengetahui persebaran suku Dayak berdasar persebaran data arkeologi, sejarah, dan tradisi di sepanjang Sungai Barito dan anak-anak sungainya di bagian tenggara Kalimantan. Metode penelitian yang digunakan adalah deskriptif dengan penalaran induktif. Data diperoleh dari berbagai sumber terutama hasil penelitian Balai Arkeologi Kalimantan Selatan dan studi pustaka. Keberadaan sungai berpengaruh pada konsep religi dan bentuk pola hunian. Dalam konsep religi, Sungai Barito sering disebut dalam mantra balian sebagai tempat tinggal pidara. Dari hasil analisis pemanfaatan ruang dan persebaran hunian diketahui pola hunian yang cenderung mengelompok tidak jauh dari sungai, meskipun ada juga yang memanjang di tepi sungai. Persebaran suku Dayak di Kalimantan bagian tenggara dimungkinkan melalui Sungai Barito dan anak-anak sungainya, seperti Sungai Negara dan Martapura.
\end{abstract}

Kata kunci : Sungai Barito, persebaran, suku Dayak, situs, balian

\begin{abstract}
Barito River is a large river which disembogues at Schwaner Muller Mountains in the northern part of Central Kalimantan, and empties in Banjarmasin towards J ava Sea. As the widest river in Indonesia, Barito is famous since hundreds of years ago to the present. Various myths and legends had been created around this river. The ancient sites scattered from downstream to upstream, such as Banjar Kingdom in Banjarmasin, Patih Muhur in Batola, and settlement of Dayak tribe along the middle to upper Barito River. This article discusses about the existence of Barito River (and its tributaries) and its connection with the Dayak dispersal in southeastern part of Kalimantan. The purpose of this paper is to determine the distribution of the Dayak based on archaeological data distribution, historical data, and tradition along the Barito River and its tributaries in the southeastern part of Kalimantan. The method used is descriptive with inductive reasoning. Data obtained from various sources specially from Balai Arkeologi Kalimantan Selatan research reports, and literature study. The river existence has affected of religion concept and occupancy patterns. In the religion concept, the Barito River often called in the balian spell as a residence of pidara. The results of spatial analysis and settlementspread is that patterns of occupancy is near the river as a cluster, although there is also linear pattern along the riverbank. The dispersal of Dayak in the southeastern part of Kalimantan is possible through of the Barito River and its tributaries, such as the Negara River and Martapura River.
\end{abstract}

Keywords : Barito River, dispersal, Dayak tribes, site, balian 


\section{PENDAHULUAN}

Kalimantan, menurut etimologi lokal, berasal dari kata kali $=$ sungai; mantan $=$ besar (Dirjen Kebudayaan 1979:1). Kata Kalimantan bisa diartikan sebagai pulau yang memiliki sungaisungai besar. Istilah tersebut sangat tepat bila dikaitkan dengan kondisi geografis Kalimantan yang dibelah oleh ratusan sungai, baik sungai besar maupun anak-anak sungainya. Sungaisungai besar yang membelah Pulau Kalimantan antara lain Sungai Kapuas dan Sungai Malawi di Kalimantan Barat; Sungai Kahayan, Sungai Mentaya atau Sungai Sampit dan Sungai Kapuas di Kalimantan Tengah; Sungai Barito di Kalimantan Selatan dan Kalimantan Tengah; Sungai Mahakam, Sungai Kayan, dan Sungai Berau di Kalimantan Timur. Pembagian wilayah di Kalimantan Tengah pada masa kolonial Belanda berdasarkan pada pola aliran sungai yang melintasi Kalimantan Tengah. Pembagian tersebut dilakukan karena permukiman masyarakat berada pada lembah-lembah sungai yang mengalir dan membagi wilayah tersebut, misalnya Kapuas di tepi Sungai Kapuas, Sampit dialiri Sungai Sampit (disebut juga Sungai Mentaya), wilayah Barito Timur dan Barito Utara yang dialiri Sungai Barito di bagian hulu. Di Kalimantan Selatan, pembagian wilayah juga berdasarkan pada aliran sungai meskipun tidak merujuk pada nama sungainya, seperti Hulu Sungai Selatan, Hulu Sungai Tengah, dan Hulu Sungai Utara.

Pada masa awal Holosen, 10.000 tahun yang lalu, berlangsung migrasi ras Australomelanesid dari daratan Asia Tenggara menuju ke arah selatan hingga ke bagian barat Nusantara. Hal ini dibuktikan dengan adanya temuan ras Australomelanesid di Gua Song Keplek dan Braholo di kawasan Gunung Sewu (di Jawa Tengah) yang berlangsung sekitar 9.000 hingga 4.500 tahun yang lalu (Widianto 2002: 227-248). Pada masa kemudian, sekitar 3.000 tahun yang lalu (ketika era neolitik), terjadi gelombang migrasi ras Mongoloid dari utara ke arah selatan melalui Filipina dan Semenanjung Malaka. Di Indonesia mereka berhenti di wilayah barat, tidak sampai wilayah timur seperti Maluku dan Papua.
Ras Australomelanesid yang semula mendominasi Indonesia wilayah barat kian berkurang dan tergantikan oleh ras Mongoloid. Beberapa ahli mengaitkan keberadaan ras Mongoloid ini dengan bangsa penutur bahasa Austronesia (Bellwood 2000:118-127). Ras Mongoloid inilah yang pada masa kemudian menurunkan orang Dayak. Awalnya mereka tinggal di daerah pantai, hingga kemudian datang kelompok Melayu (Deutro Melayu) yang mendesak kelompok sebelumnya hingga ke arah hulu sungai dan pedalaman. Itulah sebabnya mereka disebut orang Dayak, yang dalam bahasa Kenya (Dayak Kenyah) berasal dari kata daya berarti hulu sungai atau pedalaman (Umberan 1993: 32; Linblad 2012: 1-2).

Istilah "dayak" mulai populer sejak masa kolonial Belanda untuk menyebut penduduk asli Kalimantan yang masih memeluk kepercayaan tradisional, sedangkan penduduk asli yang beragama Islam disebut sebagai orang Melayu. Sebenarnya dikotomi Dayak dan Melayu versi kolonial ini tidak tepat, karena sejatinya ada kelompok etnis "dayak" yang beragama Islam dan tetap menyebut dirinya sebagai orang Dayak, bukan Melayu, misalnya orang Dayak Bakumpai di Kalimantan Selatan dan Kalimantan Tengah (Qalyubi 2012: 67-87), serta Dayak Tidung yang tersebar di wilayah Kalimantan Timur dan Kalimantan Utara (Susanto 2013: 124-125; Hartatik 2014: 46-47). Mereka tetap menyebut dirinya sebagai orang Dayak meskipun mereka adalah muslim. Setelah berdirinya Kerajaan Banjar, orang Melayu di bagian tenggara Kalimantan disebut juga sebagai orang Banjar. Banjar tidak merujuk pada etnik, melainkan kelompok yang terbentuk dari beberapa etnis, yaitu Melayu, Bukit (Meratus), Ngaju, dan Maanyan (Usman 1989: 1-4; Ideham dkk. 2007: 1-2). J.J. Ras menyatakan bahwa orang Banjar merupakan kelompok orang yang merupakan akulturasi atas beberapa etnis yang menggunakan bahasa yang lebih tua daripada bahasa Melayu dengan dialek Dayak dan campuran bahasa Jawa (Ras 1968: 7-8). Dalam hal ini, merangkum pendapat beberapa ahli tersebut, istilah orang Banjar lebih merujuk pada masyarakat yang tinggal di dalam wilayah 
Kesultanan Banjar yang memeluk agama Islam dan menggunakan bahasa Banjar.

Keberadaan orang Dayak dan orang Banjar di Kalimantan bagian tenggara tidak lepas dari keberadaan sungai, salah satunya adalah Sungai Barito. Sungai Barito merupakan sungai besar yang mengalir dari hulu Pegunungan Muller di Kalimantan Tengah hingga ke hilir melewati dua provinsi, yaitu Kalimantan Tengah dan Kalimantan Selatan menuju muara di laut Jawa. Sungai Barito disebut juga sebagai Sungai Dusun karena berhulu di daerah orang Dayak Dusun, dan juga Sungai Banjar Besar atau Sungai Banjarmasin karena bermuara di Banjarmasin. Sungai ini mempunyai aliran sepanjang hampir $1000 \mathrm{~km}$, dengan lebar antara $650 \mathrm{~m}$ hingga $800 \mathrm{~m}$, dengan kedalaman rata-rata $8 \mathrm{~m}$ (Departemen Pendidikan dan Kebudayaan 1984: 57). Di wilayah Kalimantan Selatan, Sungai Barito bercabang pada dua sungai besar, yaitu Sungai Martapura yang bermuara di Banjarmasin dan Sungai Negara di Muarabahan. Sungai Martapura mengalir di Kota Banjarmasin, Kota Martapura hingga ke arah Riam Kiwa dan berhulu di Pegunungan Meratus. Dari Muarabahan, Sungai Negara bercabang dengan Sungai Tabalong, Barabai, dan anak-anak sungainya yang mengalir di kaki Pegunungan Meratus. Sungai Barito berhulu di bagian utara dengan cabang-cabangnya, seperti Sungai Ayuh, Montalat, Teweh dan Lahei di Kalimantan Tengah (Sillander 2004: 33; lihat gambar 1).

Keberadaan Sungai Barito sangat berpengaruh dalam kehidupan orang Kalimantan sejak zaman dahulu hingga kini. Barito sekarang menjadi nama besar yang melegenda dan digunakan sebagai nama organisasi olah raga, usaha bisnis atau suatu karya manusia dengan harapan akan menjadi tumpuan dan harapan masyarakat Kalimantan, misalnya Barito Putra, Jembatan Barito (nama jembatan terpanjang di Indonesia), Barito Pacific Timber (perusahaan pengolahan kayu terbesar di Kalimantan), Perang Barito, dan rencana nama provinsi baru Barito Raya.

Bagi masyarakat Kalimantan bagian tenggara, Barito seolah menjadi legenda pada masa lalu, harapan pada masa kini dan mendatang. Apa yang sesungguhnya telah terjadi pada Sungai
Barito, terutama peranannya dalam persebaran orang Dayak yang merupakan penduduk "asli" berdasarkan data arkeologi? Artikel ini membahas peranan Sungai Barito (dan anak sungainya) dalam kaitannya dengan persebaran data arkelogi dan etnografi di sepanjang Sungai Barito. Tujuan dari tulisan ini adalah menjelaskan persebaran suku Dayak di sepanjang Sungai Barito dan memahami pentingnya jalur transportasi di Sungai Barito pada masa lalu. Data arkeologi yang berkaitan dengan keberadaan orang Dayak sangat minim, kecuali data dari masa proto sejarah yang berlanjut hingga kini sebagai tradisi. Oleh karena itu, konsep religi yang terwujud dalam bentuk peralatan dan mantra-mantra menjadi data yang akan memperkuat dalam analisis dan interpretasi dalam artikel ini.

Fokus penelitian persebaran permukiman orang Dayak di Kalimantan bagian tenggara, meliputi Kalimantan Selatan dan sebagian Kalimantan Tengah. Keberadaan orang Dayak yang kini tinggal di wilayah pedalaman berkaitan dengan kedatangan orang Melayu (Banjar) yang sekarang merupakan kelompok yang dominan di wilayah ini. Berdasarkan data arkeologi, sebelum kedatangan Melayu, Dayak telah menempati wilayah pesisir Kalimantan Selatan. Hal itu, dibuktikan dengan temuan berupa tonggaktonggak bekas tiang rumah, tiang sandong, dan alat kayu sebagai permukiman Dayak Ngaju di Cindai Alus Kabupaten Banjar. Hasil pertanggalan radiokarbon $\left({ }^{14} \mathrm{C}\right)$ dari sampel kayu tiang rumah menunjukkan angka tahun 500 Masehi (Tim Penelitian 2015: 58-61). Kedatangan orang Melayu menyebabkan orang Dayak berpindah dan masuk ke pedalaman, ke arah hulu, masuk ke anak Sungai Barito seperti Sungai Martapura, Riam Kiwa, Sungai Negara, Sungai Barabai, Sungai Batang Alay, Sungai Tabalong, Sungai Montalat, dan Sungai Tewe.

\section{METODE}

Metode penelitian yang digunakan adalah deskriptif dengan penalaran induktif. Data diperoleh dari berbagai sumber terutama dari hasil penelitian survei, ekskavasi, dan ditunjang dengan 


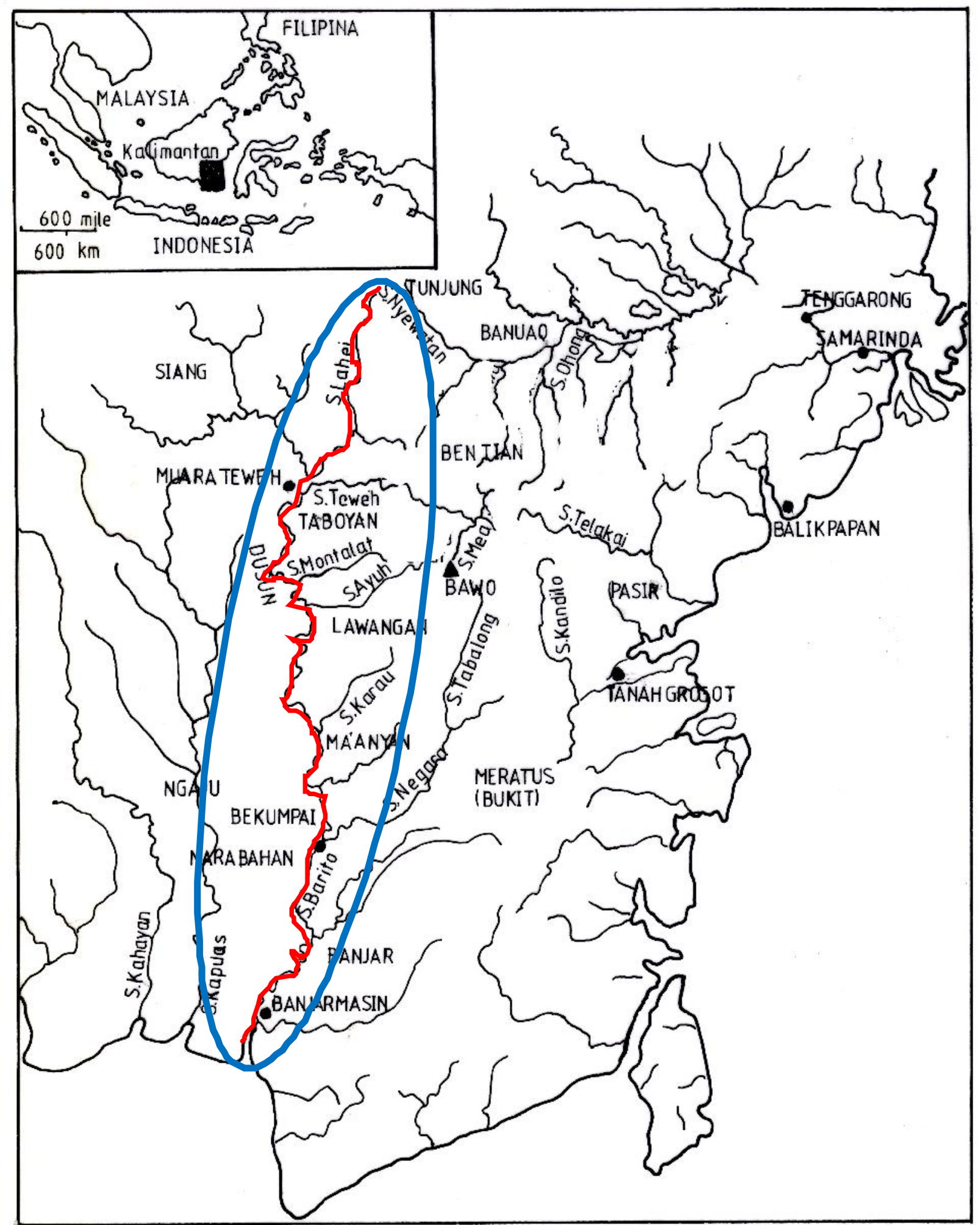

Sumber: Sillander 2004: 33 dengan perubahan

Gambar 1 Peta Sungai Barito dan Persebaran Suku Dayak di Wilayah Tenggara Kalimantan 
studi pustaka. Data arkeologi tersebut kemudian dianalisis dengan pendekatan sejarah dan etnografi yang berkaitan dengan sungai dan perahu sebagai instrumen transportasi. Analisis dalam artikel ini meliputi kegiatan penelaahan, pengelompokan, sistematisasi, penafsiran, dan verifikasi data agar fenomena memiliki nilai sosial, akademis atau ilmiah (Suprayogo dan Tobroni 2003: 191).

\section{HASIL DAN PEMBAHASAN}

\section{Situs dan Permukiman Tradisional di Daerah Aliran Sungai Barito}

Suku Dayak termasuk rumpun penutur Bahasa Austronesia yang melakukan migrasi secara bergelombang dari daratan Asia, yaitu Yunan (Cina Selatan). Dari Yunan mereka mengembara melalui Indo Cina ke Malaysia sebagai batu loncatan untuk memasuki pulau-pulau di Indonesia ${ }^{1}$. Migrasi tersebut terjadi secara bergelombang dalam kurun waktu ribuan tahun. Migrasi gelombang pertama terjadi sebelum tahun 3000 SM, yaitu kelompok Negrid dan Weddid yang sekarang telah musnah. Gelombang kedua adalah Proto Melayu yang terjadi sekitar 3000 sampai 1500 SM, mendiami wilayah pedalaman. Gelombang ketiga terjadi sekitar tahun 500 SM, yaitu kelompok Deutro Melayu yang berdiam di daerah pantai. Kelompok Proto Melayu inilah yang sisa-sisanya masih bisa ditemui di Indonesia sebagai suku yang sampai kini masih mendiami wilayah pedalaman, seperti Sasak, Toraja, Nias, dan Dayak (Coomans 1987: 3).

Masyarakat yang berdiam di daerah muara Sungai Barito pada masa itu adalah orang Melayu dan Bakumpai. Persebaran orang Melayu yang berasal dari komunitas pedagang dan nelayan terjadi sebelum abad ke-14 $\mathrm{M}$ atau semasa dengan Kerajaan Sriwijaya (abad ke- 8 hingga abad ke-14 M) (Chalmers 2007: 373-374). Namun demikian, ada pendapat yang menyatakan bahwa orang Melayu telah datang pada masa jauh sebelumnya, yaitu pada gelombang kedua yang disebut Deutro Melayu, sekitar 500 SM, dengan mendiami daerah pantai (Coomans 1987: 3). Orang Melayu mendiami daerah hilir dan anak Sungai Barito, seperti Sungai Pangeran dan Sungai Kuin. Orang-orang Melayu inilah, antara lain Patih Masih, yang berperan penting dalam pembentukan Kerajaan Banjar dengan kerjasama antara pewaris tahta Kerajaan Negara Daha dan bantuan dari Kerajaan Demak. Pada masa kemudian, orang Melayu di tenggara Kalimantan ini lebih dikenal sebagai orang Banjar dengan bahasa dialek Dayak dan Melayu, serta campuran kosa kata bahasa Jawa (Ras 1968: 8). Orang Banjar sekarang merupakan kelompok yang dominan, baik secara kuantitas maupun peran sosial politik di wilayah Kalimantan bagian tenggara.

Persebaran orang Dayak Bakumpai meliputi wilayah yang cukup luas, mulai dari Muara Sungai Barito di Muarabahan (Barito Kuala, Kalimantan Selatan) menuju ke bagian tengah Sungai Barito, yaitu di Desa Magantis, Matabu, dan Pulau Patai (di wilayah Kabupaten Barito Timur) hingga ke bagian hulu Sungai Barito, yaitu di wilayah Kabupaten Barito Utara dan Murung Raya (Desa Muara Joloi I). Di bagian tengah DAS Barito, selain Dayak Bakumpai juga berdiam orang Dayak Maanyan, Lawangan, dan Dusun. Di bagian hulu, orang Bakumpai hidup berdampingan dengan orang Dayak Ot Danum, Kareho, Siang, dan Dayak Murung (Oktrivia 2011: 49-68). Persebaran orang Dayak, seperti Bakumpai ke arah Kalimantan Timur (DAS Mahakam) dan Kalimantan Barat (DAS Kapuas Hulu) adalah karena adanya tekanan situasi ketika terjadinya perang Banjar yang meluas hingga di hulu Sungai Barito (disebut sebagai Perang Barito pada tahun

Pendapat ini mendukung teori migrasi Out of Yunan yang dipelopori oleh von Heine Geldern. Pendapat yang berbeda dengan teori migrasi Out of Taiwan yang berdasarkan riset arkeologi, linguistik, dan genetik Mitokondria DNA menyatakan bangsa penutur bahasa Austronesia berasal dari Taiwan yang menyebar lewat Filipina - Kalimantan-Sulawesi dan menyebar ke pulau-pulai kecil lainnya sekitar 2500 - 2000 SM (Bellwood 2017:174-181). 
1863). Pada masa itu, sebagian orang Bakumpai ikut bergabung dengan Temenggung Surapati dan Panglima Wangkang berhasil menenggelamkan kapal Onrust milik Belanda. Di antara suku Dayak lain yang bermukim di sepanjang Sungai Barito, orang Bakumpai adalah yang berperan paling besar. Jumlah mereka paling banyak dengan persebaran yang paling luas, dari hilir Sungai Barito ke arah hulu bahkan hingga Sungai Mahakam di Kalimantan Timur (Sjamsuddin 2014: 242).

Berbagai artefak kuno yang bukan merupakan produksi lokal (merupakan barang import) ditemukan dari penelitian arkeologi di pedalaman Kalimantan. Seperti dari penelitian Dayak Meratus di Balangan dan Kotabaru, penelitian Dayak Maanyan dan Lawangan di Barito Timur, dan Barito Utara, barang-barang produksi luar seperti keramik asing, manik-manik, dan mata uang logam banyak ditemukan. Barang-barang itu dibawa oleh para pedagang dari luar lewat jalur perdagangan dengan memanfaatkan jalur sungai. Untuk wilayah tenggara Kalimantan, jalur transportasi dimulai dari muara Sungai Barito dengan pelabuhan di Muarabahan yang kemudian pindah ke arah hilir Sungai Barito, yaitu di Bandarmasih (Banjarmasin).

Berkaitan dengan Muarabahan, ada situs yang menarik, yaitu Patih Muhur. Situs Patih Muhur berada tepat di tepi Sungai Barito, di Desa Patih Muhur Kecamatan Anjir Muara, Kabupaten Barito Kuala, Provinsi Kalimantan Selatan. Di situs ini terdapat puluhan gelondongan kayu ulin dengan diameter antara 0,5--1 meter. Penelitian Balai Arkeologi Kalimantan menemukan fakta adanya bekas-bekas pengerjaan pada tonggak kayu ulin di situs Patih Muhur, yang menunjukkan bahwa tonggak-tonggak ulin itu sengaja ditanam di tempat tersebut dengan tujuan tertentu. Tonggak ulin di situs Patih Muhur ada dua kelompok, yang diinterpretasikan sebagai dermaga dan permukiman penduduk. Interpretasi tersebut juga didukung oleh adanya temuan hasil ekskavasi berupa fragmen gerabah, keramik, dan tonggaktonggak kayu. Hasil pertanggalan radiokarbon $\left({ }^{14} \mathrm{C}\right)$ terhadap sampel dari konstruksi dermaga menghasilkan angka tahun $1310 \mathrm{M}$. Dari hasil analisis pertanggalan dan berdasar cerita dalam Hikayat Banjar, disimpulkan bahwa situs Patih Muhur ini merupakan pelabuhan (Muarabahan) yang eksis pada masa Kerajaan Negara Daha, yaitu pada masa Raja Sukarama hingga Pangeran Tumenggung (Wasita 2007: 56-58).

Patih Muhur dan Muarabahan merupakan nama yang sering disebut dalam Hikajat Banjar. Patih merupakan gelar bagi pemimpin kampung pada masa itu, Patih Muhur berarti orang yang memimpin kampung Muhur. Patih Muhur disebut bersama dengan patih-patih lainnya yang ada di sekitar anak Sungai Barito, yaitu Patih Masih, Patih Balandean, Patih Kuin, dan Balitung yang kelak mendukung Pangeran Samudra, putra mahkota Kerajaan Negara Daha yang disingkirkan (Ras 1968: 402-408). Dengan dukungan para penguasa daerah hilir dan muara, Pangeran Samudra ini berhasil menguasai pelabuhan Muarabahan yang merupakan pelabuhan penting Kerajaan Negara Daha, kemudian memindahkan pelabuhan tersebut ke Bandarmasih (kampung Patih Masih) (Ras 1968: 404). Berkat bantuan para sekutu di daerah Kalimantan dan Demak, kelompok ini juga berhasil merebut tahta Kerajaan Negara Daha, kemudian memindahkannya ke Bandarmasih, selanjutnya menjadi Kerajaan Banjar yang bercorak Islam.

Pusat Kerajaan Banjar yang pertama berada di Banjarmasin, yaitu di Kuin yang terletak di antara Sungai Kuin, Sungai Pangeran, dan Sungai Sugaling. Sungai-sungai ini merupakan anak-anak dari Sungai Barito yang bermuara di Laut Jawa, tidak jauh dari Kuin. Data arkeologi yang ditemukan dari situs ini berupa struktur bata yang (diduga) merupakan bagian dari bangunan kompleks makam Sultan Banjar, Masjid Sultan Suriansyah, keramik Cina dari abad ke-14 M hingga ke-16 M, alat besi, dan batu berhias yang merupakan bagian dari struktur. Karena posisi Kuin yang strategis dan menjadi sasaran amuk Belanda, maka pada masa pemerintahan Sultan keempat, yaitu Sultan Mustaimbillah, pusat pemerintahan dipindahkan ke arah pedalaman, yaitu di Dalam Pagar Martapura, tepatnya di tepi 
Sungai Kitanu, yang merupakan anak Sungai Martapura (Susanto dan Gunadi 2009: 64-65 dan 67). Pertentangan antara Raja Banjar dan Belanda berlanjut hingga raja-raja berikutnya. Hal tersebut menyebabkan keraton Banjar selalu dalam posisi terancam dan menjadi sasaran kemarahan Belanda, sehingga lokasi keraton berpindah untuk menghindari serangan Belanda. Meskipun berpindah, lokasi pusat kerajaan atau keraton Banjar berada tidak jauh dari sungai kecil, seperti Sungai Kitanu di Dalam Pagar dan anak Sungai Martapura di Karang Intan.

Permukiman orang Dayak sebagian besar terletak di daerah pedalaman tak jauh dari sungai. Permukiman mereka berada di sepanjang aliran Sungai Barito, mulai dari muara hingga arah hulu yang berada dalam wilayah Provinsi Kalimantan Tengah. Di muara, terdapat permukiman Dayak Bakumpai, di bagian tengah terdapat Dayak Maanyan dan Lawangan (Wasita 2004: 40), sedangkan di bagian hulu berdiam Dayak Ot Danum, Kareho, Murung, dan Bakumpai (Oktrivia 2011: 33).

Dalam mitos yang berbentuk wadian (nyanyian) orang Dayak Maanyan di wilayah Barito Timur disebutkan adanya Kerajaan Nansarunai. Kerajaan ini ada jauh sebelum berdirinya Kerajaan Banjar. Belum ada bukti tertulis dan arkeologis yang menunjukkan lokasi kerajaan tersebut, tetapi beberapa pendapat merujuk pada wilayah di sepanjang Sungai Negara dengan pusatnya di Margasari atau sekitar Sungai Tabalong. Dalam syair kuno Dayak Maanyan disebutkan bahwa Nansarunai, Kerajaan Dayak di Kalimantan, rusak oleh Majapahit (Nansarunai usak Jawa Marajampahit). Salah satu syair balian pada upacara kematian marabia Dayak Maanyan menyebutkan bahwa roh si mati mengunjungi Jawa subarang untuk mengambil peralatan upacara (Pikrianadi 1990: 99).

Dalam Hikayat Banjar disebutkan adanya kerajaan sebelum Kerajaan Banjar, yaitu Negara Dipa dan Negara Daha. Lokasi kedua kerajaan ini juga belum diketahui dengan pasti. Sebaran data arkeologi yang bercorak Hindu, yaitu Candi Agung, Candi Laras, dan Pematang Bata, yang ditemukan tidak jauh dari aliran Sungai Negara, diperkirakan sebagai bagian dari kerajaan besar ini. Negara Dipa diduga terletak di Kuripan (Barito Kuala) dengan pelabuhannya di Muara Rampiau, di tepi Sungai Barito (Ras 1968: 402). Pada masa kemudian Negara Dipa berubah menjadi Negara Daha, dan lokasinya bergeser ke Muara Hulak, dengan pelabuhannya di Muarabahan. Negara Daha berakhir setelah ditaklukan oleh Pangeran Samudra yang kelak menjadi Sultan Banjar pertama dengan gelar Sultan Suriansyah (Ideham dkk. 2007: 66-72). Namun demikian, banyak juga yang berpendapat bahwa keberadaan Candi Agung merupakan bukti dari keberadan Negara Dipa yang berlokasi disekitar Amuntai, sedangkan Negara Daha terletak di sekitar kota Negara yang kini menjadi wilayah Kecamatan Daha Selatan, Kabupaten Hulu Sungai Selatan.

Sebagai "kota tua" di tepi sungai, di wilayah Negara terdapat situs-situs yang diduga sebagai permukiman kuno, seperti situs Bajayao, Tanjung Selor, Panggandingan, dan Tambak Bitin. Dugaan itu dibuktikan dengan adanya temuan berupa terak besi, manik-manik, genteng, gerabah, alat besi, keramik asing (Cina) dari abad ke- 10-12 M, dan keramik Eropa dari abad ke-19-20 M (Sunarningsih 2015: 96-97). Bahkan tradisi pengolahan logam dan gerabah berlangsung di Negara sejak ratusan tahun silam hingga kini (Hartatik 2007: 42-61). Kota Negara terkenal sebagai pemasok senjata dan benda-benda perunggu di Kalimantan pada abad ke-16 M (Reid 1984:158-160). Carl Bock dalam perjalanannya melintasi Sungai Negara pada tahun 1810 mendeskripsikan Negara sebagai kota besar yang ramai dengan penduduk lebih dari 300.000 jiwa. Di kota itu banyak pengrajin besi, gerabah, dan perahu. Para wanita membuat keranjang dan atap dari daun nipah atau rumbia (Bock 1988: 233-234).

Selain situs di kawasan Negara, di wilayah Hulu Sungai Selatan juga terdapat situs Jambu Hulu dan Jambu Hilir yang terletak di tepi Sungai Rangas, anak Sungai Amandit yang berhulu di Bukit Meratus. Temuan dari kedua situs tersebut hampir sama, yaitu gerabah dalam berbagai bentuk periuk dan cawan, gerabah berpola hias 
tera, terak besi, batu giling, batu pelandas, batu pukul, manik-manik terakota, dan keramik dari masa Dinasti Han hingga Eropa (Nasrudin 1996/ 1997:10-15). Dari hasil pertanggalan ${ }^{14} \mathrm{C}$ terhadap sampel arang dari ekskavasi situs Jambu Hilir diketahui bahwa arang tersebut berasal dari tahun 1000 SM. Disimpulkan bahwa situs Jambu Hilir meliputi waktu yang panjang, dari masa prasejarah hingga kolonial. Berdasarkan ketersediaan bahan berupa tanah liat dan temuan terak besi, diperkirakan bahwa pembuatan gerabah dan besi sudah dilakukan di Jambu Hilir ini. Adapun situs Jambu Hulu, berdasarkan hasil pertanggalan ${ }^{14} \mathrm{C}$ terhadap sampel arang dari kotak ekskavasinya dihasilkan angka tahun sekitar 1000 Masehi (Anggraeni dan Sunarningsih 2007: 22-24).

Arah hulu dari anak Sungai Negara, di wilayah Hulu Sungai Tengah terdapat situs Pelajau yang merupakan kawasan yang terdiri dari beberapa desa (Desa Pelajau Darat, Palas, dan Benua Asam). Situs ini dikelilingi sungai kecil yang kini telah mati, antara lain Sungai Palayarum yang letaknya strategis sebagai jalur transit yang menghubungkan arah hulu (dari Sungai Batang Alay) dan arah hilir (Sungai Barabai) menuju Sungai Negara. Data arkeologi berupa keramik asing, mata uang, gerabah, arang, dan artefak berbahan kayu menunjukkan rentang waktu antara 695 SM hingga 1800 M. Pelajau yang dahulu merupakan permukiman tepi sungai mempunyai peranan yang penting terhadap perkembangan perekonomian, religi, dan nasionalisme di daerah hulu sungai (Hartatik 2015: 19-48).

Arah hulu dari Pelajau, yaitu di tepi Sungai Malang yang merupakan anak Sungai Amuntai (wilayah Hulu Sungai Utara), terdapat situs Candi Agung. Berdasarkan pertanggalan relatif dari perbandingan sumber tertulis, mitos, tradisi, dan toponim, Candi Agung dibangun pada sekitar abad ke -14 Masehi. Dari pertanggalan ${ }^{14} \mathrm{C}$ terhadap sampel kayu ulin yang kontekstual dengan Candi Agung, didapat angka tahun 728 Masehi (abad ke- $8 \mathrm{M}$ ). Hasil pertanggalan radiokarbon $\left({ }^{14} \mathrm{C}\right)$ terhadap sampel arang dari kotak gali TP 7 pada lapisan tanah hitam di bawah lapisan tanah candi menunjukkan masa abad ke-
3 SM. Ada rentang waktu yang sangat jauh antara pertanggalan relatif dan absolut. Dari pertanggalan ${ }^{14} \mathrm{C}$ dan analisis artefak hasil penggalian berupa gerabah polos tipis, berhias, batu pipisan, batu asahan, bata, dan manik-manik, ditafsirkan bahwa situs Candi Agung sudah dihuni sejak masa prasejarah hingga masa klasik atau masa pengaruh Hindu (Kusmartono dan Widianto 1998:19-23; Sunarningsih 2006: 15-34). Adapun situs Candi Laras yang terletak di anak Sungai Negara mempunyai pertanggalan ${ }^{14} \mathrm{C}$ sampel kayu ulin bekas tiang bangunan menunjukkan abad ke$14 \mathrm{M}$, sedangkan Pematang Bata berasal dari abad ke-13 M (Sulistyanto 2000: 35-38).

Di aliran anak Sungai Tabalong, Kabupaten Tabalong terdapat situs permukiman Jangkung. Dari identifikasi temuan keramik asing diketahui bahwa situs tersebut berasal dari abad 15-17 Masehi. Situs Jangkung berkaitan dengan masyarakat Dayak (Maanyan), yang hingga sekarang ini sering didatangi orang-orang Dayak dari wilayah tersebut untuk "berziarah". Sementara itu dalam cerita turun-temurun yang masih dikenal masyarakat Dayak sekarang, situs Jangkung berkaitan dengan Patih Bentar yang hidup pada masa Kerajaan Dayak yang bernama Nansarunai (Sunarningsih 2012: 41-43).

\section{Simbol Perahu dalam Upacara Adat}

Keberadaan sungai sebagai jalur transportasi tidak dapat dilepaskan dari peran perahu sebagai alat transportasi air. Kini orang Dayak tinggal di pegunungan atau daerah hulu (pahuluan), daerah yang sulit dilalui dengan jukung karena banyak terdapat riam. Sebaliknya, jukung hanya dapat digunakan untuk transportasi di sungai yang tenang, yaitu di daerah yang relatif rata di sekitar hilir hingga daerah pertengahan sungai. Logika ini menguatkan pendapat bahwa orang Dayak dahulu berasal dari daerah hilir. J ukung atau perahu kini hanya digunakan oleh orang Dayak di daerah hulu untuk menyusur sungai kecil menuju pondok di ladang atau di rawa-rawa (terutama orang Bakumpai). Pada suku Dayak lain, seperti Dayak Meratus yang tinggal di 
gunung, kini jukung hanya tinggal cerita yang diabadikan sebagai simbol pada upacara religi.

Kehidupan orang Dayak Meratus tidak lepas dari pemahaman mereka tentang konsep kepercayaan, sehingga dalam membuat peralatan tidak lepas dari konsep tersebut. Peralatan yang digunakan dalam upacara adat terdiri atas berbagai bentuk dan bahan yang sarat dengan simbol dan makna religius. Hadirnya perahu, naga, dan burung enggang dalam aruh baharin, bawanang ${ }^{2}$, dan pengobatan menandakan bahwa ketiga benda tersebut merupakan ikon penting bagi suku Dayak Meratus, yang mencerminkan keyakinan dan sejarah leluhur.

Perahu merupakan simbol perjalanan nenek moyang yang datang dari seberang dengan menggunakan perahu. Roh yang kembali ke negeri arwah juga menggunakan perahu sebagai kendaraannya. Disebutkan pada mitos Dayak di Hulu Sungai Barito dan Kahayan bahwa pada zaman purba Kalimantan adalah pulau kosong, hanya berupa samudra luas dengan dua pegunungan berbentuk pulau di tengahnya, yaitu Pegunungan Pararawan dan Bundang sebagai tempat penduduk asli Kalimantan. Nenek moyang suku Dayak datang ke Kalimantan dengan menggunakan perahu emas (Bondan 1953: 5).

Cerita kedatangan nenek moyang dengan perahu dapat dijumpai pada hampir semua suku Dayak di Kalimantan. Pada suku Dayak BahauModang dikenal cerita bahwa suatu hari ada bahtera (perahu besar) penuh muatan yang terdampar di antara dua Gunung Pararawan dan Bundang. Terjadi perkelahian antara penumpang bahtera dengan penduduk pribumi yang belum pernah saling bergaul sehingga kedua kubu saling terbunuh dan akhirnya musnah, sedangkan bahtera berubah menjadi batu, disebut sebagai Batu Banama, berada di dekat Kampung Tawan. Keberadaan perahu sebagai kendaraan awal kedatangan nenek moyang dilukiskan dalam mamang balian Dayak Bahau-Modang (Bondan 1953: 5-6).

Cerita tentang perahu banama juga terdapat pada suku Dayak Kapuas Buhang di Kalimantan Barat. Ketika masih zaman purba, ada perahu besar yang kandas karena terjepit di antara batu karang, di sebelah barat Gunung Sun-Jang. Penumpang perahu bertahan beberapa lama di dalam perahu, tetapi ketika persediaan bahan makanan habis mereka keluar untuk mencari makanan. Berjalan hingga badan lemah dan lelah mereka tidak menemukan makanan, tiba-tiba dari langit jatuh sebulir padi yang berukuran sangat besar. Mereka membelah padi itu menjadi dua, yang sebelah untuk dimasak dan dimakan, sedangkan yang sebelah dihancurkan hingga menjadi bulir-bulir padi berukuran kecil yang menjadi benih pertama untuk ditanam. Setelah mengenal bercocok tanam padi, mereka mulai hidup menetap. Akan tetapi karena lahan terbatas, akhirnya mereka menyebar mencari lahan baru hingga ke seluruh pelosok Kalimantan (Bondan 1953: 6). Persebaran ini menyebabkan mereka terpecah dalam beberapa kelompok dengan nama dan bahasa yang berbeda.

Pada suku Dayak Ngaju, peti mati berbentuk pola perahu dihiasi dengan gambar burung enggang dan naga. Burung enggang adalah simbol dunia atas yang dipersonifikasikan sebagai pihak laki-laki, sedangkan naga merupakan simbol dunia bawah yang dipersonifikasikan sebagai perempuan. Untuk mayat perempuan, peti mati dihiasi dengan gambar burung enggang, sedangkan untuk lakilaki dihiasi dengan gambar naga, merupakan antagonis sebagai simbol kesatuan kosmos (Schärer 1963: 91-97). Diyakini bahwa perjalanan roh wanita menuju ke arah hulu melalui alam atas, baru kemudian masuk ke alam kematian yang abadi. Roh laki-laki pergi ke arah hilir dengan melalui alam bawah, lalu masuk ke alam kematian (Hadiwijono 1985: 66-69). Perahu sebagai

aruh bawanang (upacara adat bawanang) merupakan pesta panen padi dari lahan lama (sudah panen lebih dari satu kali), sedangkan baharin merupakan pesta panen padi di lahan yang baru dibuka atau baru pertama panen. 
kendaraan, sedangkan naga dan burung enggang sebagai kesatuan dan keseimbangan kosmos.

Keberadaan perahu sebagai simbol dalam ritus juga dikenal oleh orang Dayak Maanyan dan Meratus. Orang Dayak Meratus di Balangan, Kalimantan Selatan, menggunakan simbol perahu dalam ritual pesta panen baharin dan bawanang. Dalam aruh bawanang dan baharin, menjelang hari terakhir aruh dibuat sesaji dengan berbagai bentuk, antara lain ancak dari bambu dan daun enau serta bentuk perahu dari bahan kayu. Dalam aruh baharin Dayak Meratus Balangan, sesaji berupa perahu naga dilarung ke sungai Balangan pada hari terakhir aruh. Pada aruh baharin Dayak Pitap, perahu hadir dalam bentuk sesungkulan, yaitu rumah perahu dengan hiasan burung dan naga di atasnya. Aruh bawanang Dayak Meratus Banjar di Hampang, hiasan burung enggang dan naga ada di atas bokor (rumah-rumahan dari kayu) yang diletakkan di dalam gaduhan. Pada aruh bawanang orang Dayak Meratus di Paramasan, bentuk perahu dan burung enggang dibuat dari daun enau, digantung pada langgatan ${ }^{3}$. Dalam keyakinan orang Dayak di Hampang, naga merupakan simbol yang menahan bumi bagian bawah. Pada ritual pengobatan balian Bawo suku Dayak Bukit di Uren, digunakan media berupa sahur, yaitu bentuk perahu kayu dengan kedua ujungnya berbentuk kepala burung enggang (lihat gambar 2). Sahur ini sebagai simbol kendaraan roh untuk kembali ke tempat asalnya sehingga tidak kembali mengganggu manusia. Tradisi balian bawo ini merupakan tradisi Dayak Bukit yang mengadopsi dari unsur budaya Dayak Maanyan (Hartatik 2012: 57-101).

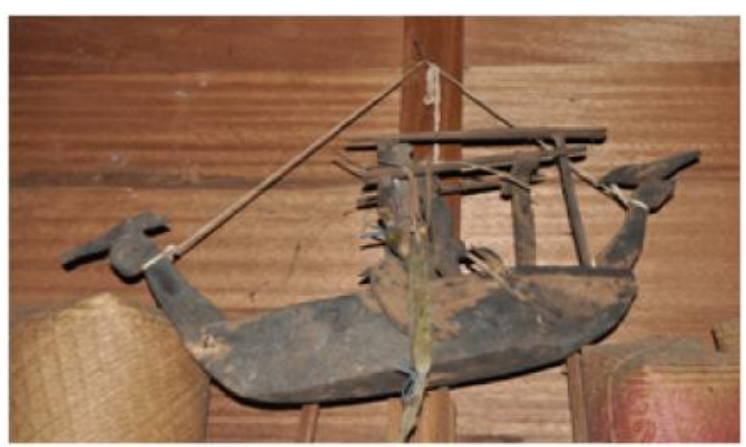

Sumber: Dok. Balai Arkeologi Kalsel

Gambar 2 Sahur, Perahu Kayu pada Balian Bawo Suku Dayak Bukit

\section{Sungai Barito dalam Mantra Balian}

Orang Dayak Meratus meyakini, bahwa semua yang ada di muka bumi ini akan kembali kepada alam, kecuali satu yang kembali pada Tuhan, yaitu roh atau pidara. Konsep tentang kepercayaan yang lekat dengan alam, merupakan dasar dari kehidupan orang Meratus. Dalam upacara adat, konsep tersebut menjelma dalam bentuk peralatan upacara, sesaji, dan doa atau mamang yang dilantunkan oleh balian. Tidak sembarang orang boleh menyebut nama roh atau pidara tanpa upacara adat, karena penyebutan nama tersebut berarti memanggil mereka.

Sungai Barito disebut dalam mantra balian sebagai tempat asal dan tinggalnya para pidara (roh yang tidak sampai ke tujuan sehingga sifatnya mengganggu manusia) ${ }^{4}$. Sungai Barito dan Pulau Banjar juga disebut dalam mantra balian segmen Hyang Lembang pada saat upacara adat

langgatan adalah tempat upacara adat yang dihiasi dengan berbagai jenis hiasan dari daun enau, berada di tengah balai adat.

Pada tahun 2012 saya dan beberapa teman melakukan penelitian religi tradisional pada masyarakat Dayak Meratus di Desa Ajung, Kecamatan Tebing Tinggi Kabupaten Balangan, Kalimantan Selatan. Suatu malam saya berempat dengan kawan saya mewawancarai balian di Desa Ajung. Balian yang masih memeluk agama leluhur, sama sekali tidak berani menyebut nama pidara atau dewa yang dipercaya, karena menurutnya harus ada ritual dan sesaji. Sementara itu, kepala adat dan sekretaris Desa Ajung yang mendampingi saya, tanpa disadari menyebut nama pidara dan alamnya berulang-ulang. Tidak berselang lama, tiba-tiba salah satu teman saya merasa pusing dan mengatakan bahwa seakan bumi seisinya berputar sehingga dia keluar dari rumah balian dan muntah-muntah. Sesampai di base camp, teman tersebut masih terus muntah-muntah dengan pandangan mata berkunang-kunang. Pada pagi harinya, tuan rumah tempat kami menginap berinisiatif memanggil balian untuk mengobati teman saya. Dalam istilah masyarakat Dayap Pitap, orang yang pusing hingga muntah-muntah tadi dipercaya terkena sangga, yaitu sakit karena disapa pidara karena banyak bercanda. Dalam konteks disapa pidara, barangkali karena pada saat itu pidara merasa diremehkan karena namanya disebut-sebut tanpa persembahan atau sesaji (Sekretaris Desa Ajung, Rahmadi, 41 tahun). Ketika balian datang mengobati teman saya di kamar, saya ikut mendampingi dan mendengarkan mantra-mantra yang dirapalkannya. Sambil membawa air dalam botol, balian merapal mantra dalam bahasa Banjar. Salah satu kalimatnya berbunyi : "....pidara nang ada di badan ini segera bulik ke asalnya di Sungai Baritu...." (Pidara yang ada di badan ini segera kembali ke asalnya di Sungai Barito). Setelah membaca mantran, balian memercikkan air ke tubuh teman saya yang sedang sakit (dilakukan oleh balian Harunisa, 66 tahun, pada 20 Mei 2011). 
baharin Dayak Meratus di Halong, Kabupaten Balangan. Pada segmen tersebut balian memanggil roh-roh penghuni tempat keramat yang ada di dunia bawah seperti di laut, kampung atau benua yang ada di Mekah Medinah, Pulau Betawi, Tanggaan Besar, Candi Laras, Candi Agung, Gunung Brahi, Pulau Banjar, dan Sungai Barito (komunikasi pribadi dengan Kinarang, 41 tahun, di Halong pada Selasa 17 Mei 2011).

Mantra balian adalah bagian dari konsep religi leluhur yang tidak tertulis tetapi bersifat oral atau cerita tutur. Dalam mitos dan foklor masyarakat Dayak Meratus disebutkan bahwa kitab suci leluhur mereka ditelan (dibakar kemudian diminum) oleh leluhur mereka yang bernama Dayuhan, sehingga ajaran suci itu telah merasuk ke dalam hati. Itulah sebabnya hingga kini mereka tidak mempunyai kitab suci. Mantra yang dirapal oleh balian diciptakan oleh para leluhur balian berdasarkan konsep kepercayaan dan pengalaman leluhur. Mantra itu berlanjut dari generasi ke generasi yang diturunkan kepada balian muda melalui proses pembelajaran dengan cara dihafal. Keberadaan Sungai Barito yang disebut dalam mantra balian menunjukkan adanya pengalaman masa lalu yang pernah dilalui oleh para leluhur.

\section{Muara Sungai Barito sebagai Gerbang Menuju Pedalaman}

Dari fakta geografis, letak Sungai Barito di bagian selatan Kalimantan dengan muara di Laut Jawa memungkinkan untuk menjadi pintu gerbang bagi masuknya imigran pada masa lalu, bahkan mereka sempat tinggal di sepanjang aliran Sungai Barito. Dari Sungai Barito, para pendatang masuk ke Sungai Martapura, kemudian bergeser ke pedalaman ke arah hulu ke arah kanan cabang dari Sungai Martapura, yaitu Sungai Riam Kanan yang berhulu di Pegunungan Meratus. Di bagian hulu Sungai Riam Kanan terdapat anak-anak sungai seperti Sungai Hajawa dan Sungai Paao di Desa Rantau Balai (lihat lampiran tabel 1).
Temuan artefaktual alat-alat paleolitik di kedua sungai itu berupa kapak perimbas, penetak, kapak genggam, kapak lonjong, kapak tipe setrika, dan kapak tipe kura-kura. Sementara itu, alat batu dari masa neolitik berupa beliung persegi pernah ditemukan di Awang Bangkal sebelum pembangunan waduk. Daerah hulu Riam Kanan ini dahulu dihuni oleh orang Dayak Bukit Bagalung, kemudian bergeser ke arah dalam (hulu) di Desa Anawit. Desa ini pun kini telah ditinggalkan oleh orang Dayak karena mereka berpindah ke tempat lain. Kini di Desa Rantau Balai ditinggali oleh orang Banjar. Ada tinggalan berupa bagian dari masjid kuno di desa ini, yaitu pataka dan bedug yang menurut penduduk merupakan bagian dari masjid sebelum adanya Desa Rantau Balai (Fajari 2012: 1-32).

Kedatangan orang-orang Melayu dari Sumatra dan Semenanjung Malaka ke Kalimantan menyebabkan orang-orang Dayak terdesak secara perlahan. Penduduk asli Kalimantan berpindah ke pedalaman dengan menelusuri sungai dengan menggunakan jukung (perahu kecil yang terbuat dari batang kayu). Permukiman orang Dayak berada di sepanjang tepi sungai dan ada juga yang agak masuk ke pedalaman, tetapi masih tetap dalam wilayah aliran sungai. Seperti masyarakat Bakumpai (Dayak yang telah memeluk Islam) di Kalimantan Tengah tersebar dalam kelompok-kelompok pada desa-desa kecil sepanjang Sungai Barito sejak dari muara hingga hulu dan anak-anak sungainya seperti Sungai Patai, Sungai Dayu, Sungai Montalat, Sungai Karau, Sungai Teweh, dan Sungai Siang Murung (Dirjen Kebudayaan 1979: 1-3; Sjamsuddin 2014: 46).

Bagian hilir Sungai Barito bermuara di Laut Jawa, terletak di wilayah Banjarmasin. Pada bagian hilir sebelah kiri sungai ini mempunyai anak-anak sungai seperti Sungai Murung, Anjir, dan Anjir Serapat, sedangkan bagian sisi kanan terdapat Sungai Banjar Kecil, Sungai Kuin, Sungai Kuin Kecil, Sungai Alalak, dan Sungai Martapura. Banyaknya aliran sungai menjadi kondisi yang menguntungkan dalam perkembangan sosial ekonomi. Dari waktu ke waktu orang Kalimantan cenderung bermukim di antara aliran sungai dan muaranya, sehingga 
terbentuk konsentrasi permukiman di daerah delta yang luas di muara sungai (Hall 1985: 3). Contohnya adalah Muarabahan yang merupakan pertemuan antara Sungai Barito dan Sungai Negara; Banjarmasin yang dikelilingi anak-anak sungai sehingga dahulu sering disebut Pulau Banjar dan menjadi pusat dagang yang ramai. Muarabahan merupakan pelabuhan penting sejak masa Kerajaan Negara Daha. Pada masa kemudian, menjelang berdirinya Kerajaan Banjar, pelabuhan ini berpindah ke arah hilir, yaitu di Banjarmasin hingga kini.

Persebaran suku Dayak di Kalimantan bagian tenggara terjadi melalui Sungai Barito dan anakanak sungainya. Pergerakan itu tidak terjadi secara langsung dari muara atau hilir ke hulu, tetapi secara bertahap. Dari muara di Banjarmasin mereka masuk ke Sungai Martapura - Sungai Riam Kanan dan Riam Kiwa dan karena terus terdesak akhirnya mereka menuju ke hulu Pegunungan Meratus dan disebut orang Dayak Meratus. Dari Muarabahan - Sungai Negara atau Sungai Bahan masuk ke Sungai Tapin, dari Sungai Negara ke Sungai Amandit, atau ke Sungai Barabai, dan Batang Alay terus menuju ke arah hulu hingga di Pegunungan Meratus. Dari Sungai Negara menuju ke arah utara hingga masuk ke Sungai Tabalong yang mempunyai banyak anak sungai, menuju hingga ke arah hulu di Pegunungan Meratus. Di Pegunungan Meratus sisi utara, berbatasan dengan Pegunungan Muller, berdiam suku Dayak Bukit (Meratus) di bagian atas, serta Maanyan, Lawangan dan Dusun di kaki pegunungan. Sungai Barito mengalir ke arah utara melalui wilayah Kabupaten Barito Timur, Barito Selatan, Barito Utara hingga Murung Raya di perbatasan dengan Kalimantan Timur, dengan anak-anak sungainya yang berhulu di Pegunungan Muller. Di wilayah ini, berdiam suku Dayak Dayak Murung, Ot Danum, Kereho, Bakumpai yang hidup di sepanjang muara Sungai Barito, Sungai Joloi, dan Sungai Murung dengan pola linier mengikuti aliran sungai (Oktrivia 2011: 53).

Pemilihan lokasi tempat tinggal di antara berbagai jenis sungai tersebut terjadi karena faktor kebutuhan dan keamanan. Orang Bakumpai dan Banjar (Melayu) memilih tinggal di daerah muara sungai besar karena mereka mempunyai keahlian dan kepentingan berdagang sehingga memilih tempat yang strategis. Muara sungai merupakan daerah yang tidak aman karena banyak perompak. Oleh karena itu orang Bakumpai dan Banjar (Melayu) memiliki sikap agresif dan berani melawan, serta selalu hidup secara berkelompok sehingga mereka mampu mengatasi para perompak. Sebaliknya, orang Dayak yang tidak memiliki keahlian berdagang cenderung melakukan kegiatan berladang atau mengumpulkan hasil hutan, mereka memilih tinggal di pedalaman yang tanah dan hutan sekitarnya masih produktif. Setiap ada kelompok pendatang baru, terutama orang Melayu, orang Dayak merasa tidak nyaman, mungkin karena adanya tekanan atau faktor keamanan sehingga mereka memilih untuk menjauh ke arah pedalaman (hulu). Itulah sebabnya hingga kini permukiman orang Dayak di Kalimantan bagian tenggara berada di pedalaman hingga daerah hulu Sungai Barito dan anak-anak sungainya. Mereka cenderung tinggal mengelompok di lembah-lembah atau punggung bukit tidak jauh dari sungai. Meskipun demikian, ada juga permukiman yang berbentuk linier di sepanjang sungai, terutama permukiman orang Dayak Bakumpai yang dikenal sebagai pedagang dan lebih terbuka menerima pengaruh dari luar.

\section{PENUTUP}

Sungai Barito merupakan sungai induk yang menjadi muara dari puluhan sungai-sungai yang mengallir di Kalimantan bagian tenggara, yaitu di Kalimantan Selatan dan sebagian wilayah Kalimantan Tengah. Situs-situs arkeologi maupun tradisi terdapat di sepanjang aliran sungainya, baik Sungai Barito maupun anak-anak sungainya hingga ke bagian hulu di Pegunungan Meratus dan Muller. Dari pola sebaran situs secara makro diketahui bahwa pemanfaatan sungai induk (Sungai Barito) lebih cenderung untuk fungsi ekonomi, yaitu perdagangan atau pelabuhan besar, seperti di Muarabahan (situs Patih Muhur) dan di bagian hilir Barito (Bandarmasih). Sementara itu, untuk permukiman kuno seperti di Jangkung, Pelajau, Jambu Hulu, dan Jambu 
Hilir justru memanfaatkan daerah aliran anak sungai yang tidak terlalu besar. Pada sisi lain, permukiman orang Dayak berada pada anak sungai kecil di pedalaman, seperti permukiman Dayak Maanyan di aliran Sungai Sirau dan Telang di kaki Pegunungan Meratus sisi barat (daerah Barito Timur), dan di daerah hulu seperti Dayak Pitap di daerah aliran Sungai Pitap, Dayak Meratus di Batang Alay dan di hulu Sungai Balangan.

Permukiman orang Dayak yang berada di daerah pegunungan tidak berpola linier atau tidak berada persis di tepi sungai, tetapi cenderung mengelompok di lembah-lembah perbukitan, dengan aliran sungai di sekitarnya (di depan, samping atau belakang agak jauh). Bagi orang Dayak, kini sungai tidak lagi menjadi jalur transpotasi utama karena mereka setiap hari pergi berladang atau berburu dengan berjalan kaki. Perahu kecil (jukung) hanya digunakan sesekali ketika mereka harus pergi ke ladang atau mengambil hasil hutan di lokasi yang terletak jauh dari kampung di seberang sungai. Berbeda halnya dengan permukiman orang Dayak di hulu Barito yang persis berada di tepi sungai atau muara, mereka memiliki pola hunian yang linier sesuai aliran sungai. Bagi mereka, sungai merupakan jalur transportasi yang efektif karena lebatnya hutan di daerah hulu Barito sulit ditempuh dengan jalur darat.

Dari hilir Sungai Barito, persebaran suku Dayak terbagi dalam beberapa jalur, yaitu jalur Sungai Martapura-Riam Kanan dan Riam Kiwa; jalur Sungai Negara dengan cabang-cabanganya seperti Sungai Tapin, Sungai Amandit, Sungai
Alay, dan Sungai Tabalong, orang Dayak sampai ke hulu di Pegunungan Meratus dan kini dikenal sebagai orang Dayak Meratus, sedangkan orang Dayak Maanyan, Dusun, dan Lawangan tinggal di kaki pegunungan, terutama yang melalui Sungai Tabalong dan Sungai Ayuh di Barito Selatan. Dari Sungai Barito yang mengarah ke utara, persebaran orang Dayak kemudian melalui anakanak sungai yang mengarah ke hulu di Pegunungan Muller, seperti Sungai Joloi dan Sungai Murung, dikenal sebagai orang Dayak Bakumpai, Murung, Siang, Kereho, dan Ot Danum.

Pengalaman nenek moyang dengan Sungai Barito sebagai jalur transportasi pertama dan utama ketika memasuki daratan Kalimantan, rupanya menjadi kenangan yang mendalam. Pengalaman tersebut diwujudkan dalam bentuk mantra balian yang menyebut Sungai Barito sebagai tempat tinggal pidara. Berkaitan dengan perjalanan sungai, dalam setiap ritual panen atau pengobatan, sesaji dalam bentuk miniatur perahu dibuat sebagai kendaraan untuk menjemput dan mengantar arwah. Pada akhir ritual, sesaji berbentuk perahu kemudian dihanyutkan ke sungai sebagai tanda kembalinya arwah ke tempat asalnya. Demikian juga bentuk peti mati yang dibuat menyerupai perahu, merupakan simbol kendaraan arwah untuk kembali ke tempat asalnya yang berada di seberang. Kehadiran nama sungai dan perahu dalam ritual merupakan simbol kedalaman pengalaman nenek moyang terhadap Sungai Barito dan perahu sebagai instrumen transportasi air pada masa lalu yang diwariskan secara turun temurun hingga kini.

\section{DAFTAR PUSTAKA}

Anggraeni dan Sunarningsih. 2007. "Permukiman Prasejarah Situs Jambu Hilir, Kecamatan Kandangan Kabupaten Hulu Sungai Selatan, Kalimantan Selatan". Laporan Penelitian Arkeologi. Banjarbaru: Balai Arkeologi Banjarmasin.
Bellwood, Peter. 2000. Prasejarah Kepulauan Indo-Malaysia. Jakarta: PT Gramedia Pustaka Utama

Bellwood, Peter. 2017. "Austronesian Studies in 2016: Where are We Now". HIm. 7-21 dalam Austronesian Diaspora a Perspective. 
Proceedings the International Symposium on Austronesian Diaspora, editor Bagyo Prasetyo, Titi Surti Nastiti dan Truman Simanjuntak. Yogyakarta: Gadjah Mada University Press.

Bock, Carl. 1988. The Head Hunters of Borneo. Singapura: Graham Brash (Pte) Ltd.

Bondan, Amir Hasan Kiai. 1953. Suluh Sejarah Kalimantan. Banjarmasin: MAT Percetakan Fadjar.

Chalmers, Iyan. 2007. "The Islamization of Southern Kalimantan: Sufi Spiritualims, Ethnic Identity, Political Activism". Studi Islamika- Indonesian J ournal for Islamic Studies 14 (3): 371-417.

Coomans, Mikhail. 1987. Manusia Daya Dulu, Sekarang dan Masa Depan. Jakarta: PT Gramedia.

Departemen Pendidikan dan Kebudayaan. 1984. Sejarah Sosial Daerah Kalimantan Selatan. Jakarta: Direktorat Sejarah dan Nilai Tradisional, Proyek Inventarisasi dan Dokumentasi Sejarah Nasional.

Dirjen Kebudayaan. 1979. Monografi Daerah Kalimantan Timur. Jakarta: Dirjenbud, Depdikbud.

Fajari, Nia M.E. 2012. "Eksplorasi Jejak Budaya di Hulu Sungai Riam Kanan". Berita Penelitian Arkeologi Balai Arkeologi Banjarmasin 6 (1): 1-32.

Hadiwijono, Harun. 1985. Religi Suku Murba di Indonesia. Jakarta: BPK Gunung Mulia.

Hall, Kenneth R. 1985. Maritime Trade and State Development in Early Southeast Asia. Honolulu: University of Hawaii Press.

Hartatik. 2007. "Teknologi Pembuatan Alat Logam di Nagara Kabupaten Hulu Sungai Selatan, Kalimantan Selatan". HIm. 42-61 dalam Perkembangan Teknologi dan Ekonomi dalam Perspektif Arkeologi, editor Herry Porda Nugroho Putro. Banjarbaru: Balai Arkeologi Banjarmasin. Tradisional Suku Dayak Meratus di Kabupaten Balangan, Kalimantan Selatan".
Berita Penelitian Arkeologi Balai Arkeologi Banjarmasin 6: 57-100. . 2014. "Perbandingan Bahasa dan Data Arkeologi pada Suku Tidung dan Dayak di Wilayah Nunukan: Data Bantu Untuk Rekonstruksi Sejarah dan Perubahan Budaya". Naditira Widya Vol. 8 (1): 29-48.

____-. 2015. "Keberlanjutan Budaya di Pelajau". Kindai Etam 1 (1): 19-48.

Ideham, Suriansyah; Sjarifuddin, Gazali Usman, Zainal Arifin Anis, dan Wajidi. 2007. Orang Banjar dan Kebudayaannya. Banjarmasin: Balitbangda Prov. Kalsel.

Kusmartono, Vida P.R., dan Harry Widianto. 1998. "Ekskavasi situs Candi Agung Kabupaten Hulu Sungai Selatan Kalimantan Selatan". Berita Penelitian Arkeologi Balai Arkeologi Banjarmasin (2): 1-65.

Lindblad, J. Thomas. Antara Dayak dan Belanda, Sejarah Ekonomi Kalimantan Timur dan Kalimantan Selatan 1880-1942. Malang: Lilin Persada Press.

Nasruddin. 1996/1997. "Ekskavasi Situs Jambu Hilir Kabupaten Hulu Sungai Selatan Provinsi Kalimantan Selatan". Laporan Penelitian Arkeologi. Banjarbaru: Balai Arkeologi Banjarmasin.

Oktrivia, Ulce. 2011. "Potensi dan Karakteristik Situs Arkeologi di Kawasan Pegunungan Muller". Berita Penelitian Arkeologi Balai Arkeologi Banjarmasin 5 (1): 49-68.

Pikrianadi, Usah. 1990. “Upacara Mia (Mambatur) dalam Perspektif Budaya Suku Dayak Maanyan Desa Warukin Kabupaten Tabalong". Skripsi. Banjarmasin: FKIP Universitas Lambung Mangkurat.

Qalyubi, Imam. 2012. "Suku Bakumpai, Sebuah Pergulatan Identitas Antara Dayak dan Melayu: Sebuah Tinjauan Budaya dan Linguistik". J urnal Studi Agama dan Masyarakat 6 (2): 67-87.

Ras, JJ. 1968. HikajatBandjar: A S tudy Indonesia Malay Historiography. The Hague: Martinus Nijhoff. 
Reid, Anthony, 1984, "The Pre-colonial Economy of Indonesia". Bulletin of Indonesian E conomic Studies 20(2): 151-67.

Schärer, Hans. 1963. Ngaju Religion The Conception of God among a South Borneo People. The Hague: Martinus Nijhoff.

Sillander, Kenneth. 2004. "Expressed Through Social Action among the Bentian of Indonesian Borneo. Helsinki (Finland): Research Institute Swedish School of Social Science University of Helsinki". Diunduh $16 \quad$ September 2013 (http:ethesis.helsinki.fi/julkaisut/val/sosio/ vk/sillander/actingau.pdf.).

Sjamsuddin, Helius. 2014. Pegustian dan Temenggung. Akar Sosial, Politik, Etnis dan Dinasti Perlawanan di Kalimantan Selatan dan Kalimantan Tengah 1856-1906. Yogyakarta: Penerbit Obor.

Sulistyanto, Bambang. 2000. "Umur Candi Laras dalam Panggung Sejarah Indonesia Kuna". Berita Penelitian Arkeologi Balai Arkeologi Banjarmasin (7): 1-45.

Sunarningsih. 2006. "Ekskavasi Situs Candi Agung Kabupaten Hulu Sungai Utara, Kalimantan Selatan". Berita Penelitian Arkeologi Balai Arkeologi Banjarmasin (17): 15-34. 2012. "Penelitian Arkeologi Situs

Pulau Jangkung, Kabupaten Tabalong, Kalimantan Selatan". Laporan Penelitian Arkeologi. Banjarbaru: Balai Arkeologi Banjarmasin. 2015. "DAS Barito dan Jejak Kehidupan Masyarakat Proto Sejarah". HIm.85-116 dalam Budaya di Kawasan Pegunungan Meratus dalam Perspektif Arkeologi, editor Bambang Sulistyanto. Banjarbaru: Balai Arkeologi Banjarmasin.
Suprayogo, Imam dan Tobroni, 2003. Metodologi Penelitian Sosial-Agama. Bandung: PT Remaja Rosdakarya.

Susanto, Nugroho Nur dan Gunadi. 2009. "Perluasan Pusat-Pusat Kerajaan Banjar". Berita Penellitian Arkeologi Balai Arkeologi Banjarmasin 3(1): 62-92.

Susanto, Nugroho Nur. 2013. "Pengaruh Islam Terhadap Identitas Tidung Menurut Bukti Arkeologi". Naditira Widya 7(2): 117-129.

Tim Penelitian. 2015. "Laporan Penelitian Permukiman Kuno di Kawasan Cindai Alus Kabupaten Banjar, Kalimantan Selatan". Laporan Penelitian Arkeologi. Banjarbaru: Balai Arkeologi Banjarmasin.

Umberan, Musni. 1993. Sejarah Kebudayaan Kalimantan. Jakarta: Proyek Inventarisasi dan Dokumentasi Sejarah Nasional.

Usman, Gazali. 1989. Orang Banjar dalam Sejarah. Banjarmasin: Lambung Mangkurat University Press.

Wasita. 2004. "Penelitian Perbedaan Ritual Kematian pada Tiga Kelompok Budaya di Masyarakat Dayak Maanyan di Barito Timur". Laporan Penelitian Arkeologi. Banjarbaru: Balai Arkeologi Banjarmasin. . 2007. "Ekskavasi Permukiman Lahan Basah di Situs Gambut, Kabupaten Banjar dan Patih Muhur, Kabupaten Barito Kuala, Kalimantan Selatan". Laporan Penelitian Arkeologi. Banjarbaru: Balai Arkeologi Banjarmasin.

Widianto, Harry. 2002. "Prehistoric Inhabitans of Gunung Sewu". HIm. 227-248 dalam Gunung Sewu in Prehistoric Times, editor Truman Simanjuntak. Yogyakarta: Gajdah Mada University Press. 


\section{LAMPIRAN}

Tabel 1 Anak-Anak Sungai Barito, Situs, dan Pendukung Budayanya

\begin{tabular}{|c|c|c|c|c|c|c|}
\hline $\begin{array}{l}\text { Sung ai } \\
\text { Induk }\end{array}$ & $\begin{array}{c}\text { A nak Sungai } \\
\text { ke-1 }\end{array}$ & $\begin{array}{c}\text { Anak } \\
\text { Sungai ke-2 }\end{array}$ & Jenis $S$ ungai & Hulu & S itus & Pendukung Bud aya \\
\hline \multirow[t]{10}{*}{$\begin{array}{l}\text { S ungai } \\
\text { B arito }\end{array}$} & & & \multirow{2}{*}{ Sungai Bes ar (induk) } & \multirow{2}{*}{$\begin{array}{l}\text { Pegunungan } \\
\text { Muller }\end{array}$} & $\begin{array}{l}\text { bagian hilir: Path } \\
\text { Muhur (pelabuhan } \\
\text { Muarabahan) }\end{array}$ & Dayak Bakum pai, \\
\hline & & & & & $\begin{array}{l}\text { bagian hulu: Kapal } \\
\text { Onrust }\end{array}$ & $\begin{array}{l}\text { Melayu (Banjar), } \\
\text { Dayak, kolonial }\end{array}$ \\
\hline & \multirow[t]{8}{*}{\begin{tabular}{|l|} 
Sungai \\
Martapura
\end{tabular}} & & \multirow{2}{*}{$\begin{array}{l}\text { Anak Sungai B arito } \\
\text { dengan muar a di } \\
\text { Banjarmasin }\end{array}$} & \multirow{2}{*}{$\begin{array}{l}\text { Pegunungan } \\
\text { Meratus }\end{array}$} & $\begin{array}{l}\text { Keraton B anjar di Kuin, } \\
\text { di Dalam Pagar } \\
\text { Martapura }\end{array}$ & Banjar (Melayu) \\
\hline & & & & & $\begin{array}{l}\text { Per mukiman Dayak } \\
\text { (Ngaju) di Cindai Alus }\end{array}$ & Dayak Ngaju \\
\hline & & \multirow[t]{3}{*}{ Sungai Riam Kiwa } & \multirow{3}{*}{$\begin{array}{l}\text { Anak Sungai } \\
\text { Martapura }\end{array}$} & \multirow{3}{*}{$\begin{array}{l}\text { Pegunungan } \\
\text { Meratus }\end{array}$} & $\begin{array}{l}\text { Keraton B anjar di } \\
\text { Karang Intan }\end{array}$ & Dayak, Banjar \\
\hline & & & & & $\begin{array}{l}\text { Tambang batubara } \\
\text { Belanda Or ange } \\
\text { Nassau di Pengar on } \\
\end{array}$ & Banjar, Dayak, kolonial \\
\hline & & & & & Tradisi & $\begin{array}{l}\text { Dayak Meratus } \\
\text { (Paramasan) }\end{array}$ \\
\hline & & \multirow[t]{3}{*}{$\begin{array}{l}\text { Sungai Riam } \\
\text { Kanan }\end{array}$} & \multirow[t]{3}{*}{$\begin{array}{l}\text { Anak Sungai } \\
\text { Martapura }\end{array}$} & \multirow[t]{3}{*}{$\begin{array}{l}\text { Pegunungan } \\
\text { Meratus }\end{array}$} & $\begin{array}{l}\text { Situs paleolitik di hulu } \\
\text { Riam Kanan, situs } \\
\text { neolitik di Awang } \\
\text { Bangkal }\end{array}$ & tidak diketahui \\
\hline & & & & & $\begin{array}{l}\text { tradisi (berladang } \\
\text { sistem tebas bakar) }\end{array}$ & $\begin{array}{l}\text { Dayak Bukit Bagalung } \\
\text { (Meratus) }\end{array}$ \\
\hline & & & & & $\begin{array}{l}\text { pet aka dan bedug } \\
\text { masjid di Rantau Balai }\end{array}$ & orang Banjar \\
\hline & \multirow[t]{10}{*}{$\begin{array}{l}\text { Sungai } \\
\text { NegaraßB ahan }\end{array}$} & & \multirow{2}{*}{$\begin{array}{l}\text { Anak Sungai B arito } \\
\text { bermuara di } \\
\text { Muarabahan }\end{array}$} & \multirow{2}{*}{$\begin{array}{l}\text { Pegunungan } \\
\text { Meratus }\end{array}$} & $\begin{array}{l}\text { Candi Laras di } \\
\text { Margasari }\end{array}$ & Pemeluk Hindu \\
\hline & & & & & $\begin{array}{l}\text { situs permukiman } \\
\text { Penggandingan, } \\
\text { Bajayau }\end{array}$ & Melayu \\
\hline & & Sungai Tapin & Anak Sungai Negara & $\begin{array}{l}\text { Pegunungan } \\
\text { Meratus }\end{array}$ & $\begin{array}{l}\text { Banua Hanyar dan } \\
\text { Banua Halat } \\
\end{array}$ & Banjar dan Dayak \\
\hline & & Sungai $A m$ andit & $\begin{array}{l}\text { Cabang Sungai } \\
\text { Negara, Hulu Sungai } \\
\text { Selatan }\end{array}$ & $\begin{array}{l}\text { Pegunungan } \\
\text { Meratus }\end{array}$ & $\begin{array}{l}\text { Situs permukim an } \\
\text { Jambu, Jambu Hilir }\end{array}$ & $?$ \\
\hline & & Sungai Barabai & $\begin{array}{l}\text { Cabang Sungai } \\
\text { Tabalong, bermuara } \\
\text { di Barabai }\end{array}$ & $\begin{array}{l}\text { Pegunungan } \\
\text { Meratus }\end{array}$ & $\begin{array}{l}\text { Situs permukim an } \\
\text { Pelajau (di tepi Sungai } \\
\text { Pelajau, anak Sungai } \\
\text { Barabai) }\end{array}$ & Melayu (Banjar) \\
\hline & & Sungai Alay & $\begin{array}{l}\text { Bermuara di wilayah } \\
\text { Hulu Sungai Tengah }\end{array}$ & $\begin{array}{l}\text { Pegunungan } \\
\text { Muller }\end{array}$ & tradisi & Dayak M eratus \\
\hline & & \multirow[b]{2}{*}{ Sungai Tabalong } & \multirow{2}{*}{$\begin{array}{l}\text { Anak Sungai Negara } \\
\text { di Tabalong }\end{array}$} & \multirow{2}{*}{$\begin{array}{l}\text { Pegunungan } \\
\text { Meratus }\end{array}$} & $\begin{array}{l}\text { Situs permukiman } \\
\text { Jang kung }\end{array}$ & Dayak Maanyan \\
\hline & & & & & $\begin{array}{l}\text { Tradisi di Warukin, } \\
\text { Haus, Muara Uya, } \\
\text { Kinar um }\end{array}$ & $\begin{array}{l}\text { Dayak Deah, Dayak } \\
\text { Maanyan, Dayak } \\
\text { Dusun }\end{array}$ \\
\hline & & Sungai Balangan & $\begin{array}{l}\text { Cabang Sungai } \\
\text { Tabalong di } \\
\text { Balangan } \\
\end{array}$ & $\begin{array}{l}\text { Pegunungan } \\
\text { Meratus }\end{array}$ & tradisi & $\begin{array}{l}\text { Dayak M aanyan, } \\
\text { Dayak M eratus, }\end{array}$ \\
\hline & & Sungai Pitap & $\begin{array}{l}\text { Tebing TInggi } \\
\text { (Balangan) }\end{array}$ & $\begin{array}{l}\begin{array}{l}\text { Pegunungan } \\
\text { Meratus }\end{array} \\
\end{array}$ & tradisi & Dayak Pitap \\
\hline & $\begin{array}{l}\text { Sungai } \\
\text { Mangkatip }\end{array}$ & Anak Sungai B arito & $\begin{array}{l}\text { wilayah Barito } \\
\text { Selatan }\end{array}$ & $\begin{array}{l}\text { Perbatasan } \\
\text { Meratus-Muller }\end{array}$ & Tradisi & Dayak Maanyan \\
\hline & Sungai Karau & Anak Sungai B arito & $\begin{array}{l}\text { wilayah Barito } \\
\text { Selatan }\end{array}$ & $\begin{array}{l}\text { Perbatasan } \\
\text { Meratus-Muller }\end{array}$ & Tradisi & Dayak Maanyan \\
\hline & Sungai Ayuh & Anak Sungai B arito & $\begin{array}{l}\text { wilayah Barito } \\
\text { Selatan } \\
\end{array}$ & $\begin{array}{l}\text { Perbatasan } \\
\text { Meratus-Muller }\end{array}$ & $\begin{array}{l}\text { Situs Penguburan Batu } \\
\text { Utek dan tradisi }\end{array}$ & $\begin{array}{l}\text { Dayak Lawangan dan } \\
\text { Bawo }\end{array}$ \\
\hline & Sungai Lahei & Anak Sungai B arito & wilayah Barito Utara & $\begin{array}{l}\begin{array}{l}\text { Pegunungan } \\
\text { Muller }\end{array} \\
\end{array}$ & Tradisi & Dayak Lahei \\
\hline & $\begin{array}{l}\text { Sungai } \\
\text { Montalat }\end{array}$ & Anak S ungai B arito & wilayah B arito Utara & $\begin{array}{l}\text { Pegunungan } \\
\text { Muller }\end{array}$ & Situs benteng kolonial & Kolonial Belanda \\
\hline & Sungai Teweh & Anak Sungai B arito & wilayah Barito Utara & $\begin{array}{l}\text { Pegunungan } \\
\text { Muller }\end{array}$ & Tradisi & $\begin{array}{l}\text { Dayak Bakum pai, } \\
\text { Dayak Taboyan, } \\
\text { Dayak Siang }\end{array}$ \\
\hline & Sungai Laung, & Anak S ungai B arito & $\begin{array}{l}\text { Bermuara di wilayah } \\
\text { Murung Raya }\end{array}$ & $\begin{array}{l}\text { Pegunungan } \\
\text { Muller }\end{array}$ & Tradisi & $\begin{array}{l}\text { Dayak Ot Danum, } \\
\text { Kareho, Bakum pai, } \\
\text { Murung }\end{array}$ \\
\hline & $\begin{array}{l}\text { Sungai Babuat } \\
\text { dan Joloi }\end{array}$ & Anak Sungai B arito & $\begin{array}{l}\text { Bermuara di wilayah } \\
\text { Murung Raya }\end{array}$ & $\begin{array}{l}\text { Pegunungan } \\
\text { Muller }\end{array}$ & Tradisi & $\begin{array}{l}\text { Dayak Ot Danum, } \\
\text { Kareho, Bakum pai, } \\
\text { Murung }\end{array}$ \\
\hline & Sungai Bus ang & Anak Sungai Barito & $\begin{array}{l}\text { Bermuara di wilayah } \\
\text { Murung Raya }\end{array}$ & $\begin{array}{l}\text { Pegunungan } \\
\text { Muller }\end{array}$ & Tradisi & $\begin{array}{l}\text { Dayak Ot Danum, } \\
\text { Kareho, Bakum pai, } \\
\text { Murung }\end{array}$ \\
\hline
\end{tabular}

Sumber: Laporan Penelitian Balai Arkeologi Kalimantan Selatan yang telah diolah oleh penulis 